\title{
Quantification and characterization of knotwood extractives of 12 European softwood and hardwood species
}

\author{
Zineb Kebbi-Benkeder • Francis Colin • Stéphane Dumarçay • \\ Philippe Gérardin
}

Received: 12 June 2014 / Accepted: 3 October 2014 /Published online: 24 October 2014

(C) INRA and Springer-Verlag France 2014

\begin{abstract}
- Key message Extractives are present in much larger amounts in knotwood than in heartwood in the 12 tested hardwood and softwood species. The chemical identity of the extractives varies largely among species, lignans being only present in softwood species.

- Context Extractives from knotwood may constitute an important source of new chemicals and remain still poorly known.
\end{abstract}

Handling Editor: Jean-Michel Leban

Highlights Extractives are present in much larger amounts in knotwood than in heartwood in the 12 tested hardwood and softwood species. The chemical identity of the extractives varies largely among species, lignans being only present in softwood species.

Contribution of the co-authors Zineb Kebbi-Benkeder: carrying out the experiments, interpreting the results and writing the first draft of the paper.

Francis Colin: co-designing and coordination of the $\mathrm{PhD}$ thesis, species selection and tree sampling, interpreting the results and correction of the paper.

Stéphane Dumarçay: supervising the chemical analysis, interpreting the results and correction of the paper.

Philippe Gérardin: co-designing and coordination of the $\mathrm{PhD}$ thesis, supervision of chemical analysis, interpreting the results and correction of the paper.

Z. Kebbi-Benkeder $\cdot$ F. Colin

AgroParisTech, UMR 1092 LERFOB, 54000 Nancy, France

Z. Kebbi-Benkeder $\cdot$ F. Colin

INRA, UMR 1092 LERFOB, 54280 Champenoux, France

Z. Kebbi-Benkeder $\cdot$ S. Dumarçay $\cdot$ P. Gérardin

Université de Lorraine, EA 4370 LERMAB,

54500 Vandoeuvre-les-Nancy, France

P. Gérardin $(\bowtie)$

Faculté des Sciences et Technologies, Université de Lorraine, Bld des Aiguillettes, BP 70239, 54506 Vandoeuvre-les-Nancy Cédex, France e-mail: Philippe.Gerardin@univ-lorraine.fr
- Aims The content of extractives (and particularly lignans) in knots was compared to that of heartwood in a number of different European softwood and hardwood species.

- Methods Twelve species characteristic of European forests were sampled. Extractions were carried out with four solvents of increasing polarity (dichloromethane, acetone, toluene/ ethanol and water). Gas chromatography-mass spectrometry (GC-MS) was used for the identification of the compounds present in acetone extracts which are expected to contain lignans.

- Results In all tested species, knotwood presented larger contents of extractives than heartwood. The main compounds were lignans, stilbenes and flavonoids, lignans being present only in softwood species. With the exception of oak, knotwood in softwood species contain larger amounts of extractives than that in hardwood species.

- Conclusion The chemical nature of extractives present in knotwood varies with species. Their amount is generally much higher in softwood than heartwood species.

Keywords Extractive content $\cdot$ Knot $\cdot$ Softwood · Hardwood $\cdot$ Lignan $\cdot$ Flavonoid

\section{Introduction}

Knots are the junctions between the tree stem and its branches which support leaves. Leaves are essential for tree photosynthesis and growth. Once a tree is harvested, the knots constitute the main defect in stem wood. Knots cause defects because this portion of stem wood is characterized by almost horizontal fibres with higher density and darker coloration. Thus, knots become undesirable in wood industries, especially in not only paper mills since high energy consumption is needed to defibrate knotwood during mechanical pulping but also in sawmills since their presence decreased mechanical 
properties and commercial value of sawn products. Various studies revealed the richness of knotwood regarding their extractive components compared to heartwood in the case of several conifers such as spruce, fir and pine species (Holmbom et al. 2003; Willför et al. 2003a, b, 2004a, b; Sekine et al. 2013). Anderegg and Rowe (1974) reported that even up to $30 \%$ of a glassy resin of economic interest can be obtained from the knots of Parana pine (Araucaria angustifolia). Softwood knots, which are available as byproducts of pulp and paper industries, have been largely investigated and identified to contain not only lignans in concentrations up to several hundred times higher than heartwood (Willför et al. 2003a, b, 2004a, b) but also oligolignans (Willför et al. 2004c). Flavonoids have also been detected in softwood knots but in lower amounts than lignans, while stilbenes and juvabione have been reported predominately in knots of pines and firs, respectively (Willför et al. 2003b, 2004b).

Only a few hardwoods have been investigated such as willow, acacia and poplar species (Pohjamo et al. 2003; Pietarinen et al. 2005, 2006a). Their knots were found to contain lower extractive contents than coniferous knots. However, hardwood knots contained still higher quantities than the corresponding heartwood and flavonoids which were detected as the main components. Lignans have not been reported in hardwood knots except in one study in which the authors detected lignan-like compounds in beech and birch knots (Lindberg et al. 2004).

High levels of extractives in softwood knotwood have been interpreted as a response to stresses that the base of branch is subjected to (Willför et al. 2003b; Piispanen et al. 2008). Branches and thus knots develop reaction wood to face mechanical loads such as wind and snow, especially in the case of softwoods which do not lose their leaves during winter. Since lignans have been identified as lignin precursors (Lundquist et al. 2003), the presence of these latter ones may be due to higher lignin content around the knots in response to mechanical stress. On the other hand, knots can be considered as easy access for pathogen attacks, which may justify higher extractive contents to avoid infestation of the stem. Thus, the extractives may act either chemically because of their toxicity or physically because of the barrier they constitute to protect the rest of the non-decayed wood (Kirker et al. 2013).

The aim of the present study was thus to investigate the amounts and the nature of knotwood extractives of different European softwood and hardwood species. According to the numerous studies describing high amounts of lignans in knots of different softwoods and to their potential valorization, a quite particular attention was carried to these latter ones (Eklund et al. 2005; Willför et al. 2003a, b, 2004a, b). This is considered not only in order to consider potential valorization of these extractives but also to have a deeper insight of their role in the tree. For this purpose, 12 softwood and hardwood species were selected and their knotwood extractive contents determined after extraction with different solvents. The composition of acetone extracts, supposed to contain the highest content of lignans, was determined by gas chromatography-mass spectrometry (GC-MS) and compared to literature data.

\section{Material and methods}

\subsection{Woody material}

Five softwood species (Abies alba Mill., Picea abies (L.) Karst., Pseudotsuga menziesii (Mirb.) Franco, Larix decidua Mill and Pinus sylvestris L.) and seven hardwood species (Alnus glutinosa (L.) Gaertn, Prunus avium L., Robinia pseudoacacia L., Carpinus betulus L., Fagus sylvatica L., Fraxinus excelsior L. and Quercus petraea (Mattus.) Liebl) (Rameau et al. 1989) were selected for this study (Table 1). For each species, one healthy tree was felled in winter 2012 2013. All the trees were sampled in the Champenoux and Amance forests, near Nancy in northeast France.

On every trunk, a disc was sawn both at the stump and at a height of $1.3 \mathrm{~m}$. Above these two discs, several discs were sawn along the length of the trunk containing either dead or living knots. Knots, dead or alive, were removed from each disc using a wood chisel, while heartwood was sampled from the disc sawn at a height of $1.3 \mathrm{~m}$. The inner part of that disc was sampled to be sure that only heartwood was taken, especially in the case of non-coloured heartwood species (beech, spruce, fir, etc.). The annual rings were counted on the stump disc. Data on the sampled trees and the number of knots investigated are summarized in Table 1. All samples were dried at $50{ }^{\circ} \mathrm{C}$ until mass stabilization. For each tree, all knots (dead or alive) were mixed all together and ground to fine sawdust with particle size between 0.2 and $0.4 \mathrm{~mm}$ before drying at $103{ }^{\circ} \mathrm{C}$ to be sure to have a screening as large as possible of potential secondary metabolites. Heartwood was ground to similar grain size and dried at $103{ }^{\circ} \mathrm{C}$. All samples were frozen until they were used for extraction.

\subsection{Extraction}

Each powder was Soxhlet-extracted using four successive solvents of increasing polarity: methylene chloride, acetone, toluene/ethanol $(2 / 1, v / v)$ and water. After each extraction, organic solvents were evaporated under vacuum using a rotary evaporator while water was freeze-dried. Dried extractives were stored in a freezer before GC-MS analyses. 
Table 1 Data about the trees and the number of knots sampled

\begin{tabular}{llllll}
\hline Species & Common name & Age (annual rings) & $\begin{array}{l}\text { Height } \\
(\mathrm{m})\end{array}$ & $\begin{array}{l}\text { Diameter } \\
(\mathrm{cm})\end{array}$ & $\begin{array}{l}\text { Knots } \\
\text { sampled }\end{array}$ \\
\hline Abies alba & Silver fir & 50 & 22.4 & 21 & 9 \\
Picea abies & Norway spruce & 42 & 19.4 & 25 & 8 \\
Pseudotsuga menziesii & Douglas fir & 47 & 21.4 & 23 & 10 \\
Larix spp. & Larch & 55 & 23.3 & 25 & 14 \\
Pinus sylvestris & Scots pine & 40 & 23.2 & 30 & 6 \\
Alnus glutinosa & Alder & 29 & 20.7 & 26 & 14 \\
Prunus avium & Cherry & 28 & 17.1 & 21 & 9 \\
Robinia pseudoacacia & Black locust & 37 & 20.2 & 28 & 10 \\
Carpinus betulus & Hornbeam & 101 & 22.1 & 26 & 6 \\
Fagus sylvatica & Beech & 98 & 17.9 & 22 & 9 \\
Fraxinus excelsior & Ash & 83 & 20.2 & 33 & 7 \\
Quercus petraea & Oak & 90 & 21.9 & 27 & 13 \\
\hline
\end{tabular}

\subsection{GC-MS analyses}

Based on literature (Willför et al. 2003a, b), mainly acetonic extracts were investigated. One to $2 \mathrm{mg}$ of the dried acetone extracts were silylated by adding $80 \mu \mathrm{L}$ of BSTFA/ TMSCl $(99 / 1)$ and heated at $50{ }^{\circ} \mathrm{C}$ for $12 \mathrm{~h}$. Then, the solvent was evaporated and extract derivatives were diluted in $1 \mathrm{~mL}$ ethyl acetate and transferred into a glass vials for gas chromatography analysis. GC-MS analysis was performed on a Clarus 500 gas chromatograph coupled to a Clarus $500 \mathrm{MS}$ quadrupole mass spectrometer (Perkin Elmer Inc., USA). Gas chromatography was carried out on a $5 \%$ diphenyl $/ 95 \%$ dimethyl polysiloxane fused-silica capillary column (DB- $5 \mathrm{~ms}, 30 \mathrm{~m} \times 0.25 \mathrm{~mm}, 0.25-\mu \mathrm{m}$ film thickness, J\&W Scientific, USA) with helium as carrier gas at a constant flow of $1 \mathrm{~mL} / \mathrm{min}$. The gas chromatograph was equipped with an electronically controlled split/ splitless injection port. The injection $(1 \mu \mathrm{L})$ was performed at $250{ }^{\circ} \mathrm{C}$ in the splitless mode. The oven temperature programme was as follows: $80^{\circ} \mathrm{C}$ for $2 \mathrm{~min}$, increase from 80 to $190{ }^{\circ} \mathrm{C}$ at a rate of $10^{\circ} \mathrm{C} / \mathrm{min}$, increase from 190 to $280{ }^{\circ} \mathrm{C}$ at a rate of $15{ }^{\circ} \mathrm{C} / \mathrm{min}$ and hold for $5 \mathrm{~min}$, then $10{ }^{\circ} \mathrm{C} / \mathrm{min}$ until $300{ }^{\circ} \mathrm{C}$ hold for $14 \mathrm{~min}$. Ionization was achieved under the electron impact mode $(70 \mathrm{eV}$ ionization energy). The source and transfer line temperatures were 250 and $300{ }^{\circ} \mathrm{C}$, respectively. Detection was carried out in scan mode: $m / z=45$ to $m / z=800$. The detector was switched off in the initial $2 \mathrm{~min}$ (solvent delay). Compounds were identified by comparison with spectra from the NIST (US National Institute of Standards and Technology, Gaithersburg, MD, USA) mass spectral library (Edition of 2005) and published mass spectra of lignans (Ekman 1976; 2002; Willför et al. 2005; Smeds et al. 2012). Pure taxifolin, dihydrorobinetin and robinetin were purchased from Extrasynthese, France, and used as reference compounds. Peaks on the chromatograms were integrated to determine the relative concentrations of the main compound families.

\section{Results}

Figure 1 presents the knotwood and heartwood extractive content of the 12 tree species according to the extraction solvent.

The total amount of knotwood and heartwood extractives is reported as the sum of the four successive extractions. Except in the case of black locust, knots of all species contained higher quantities of extractives than heartwood. The overall knotwood extractives content ranged from a slightly less than $40 \%$ of the dry sawdust in the case of larch or Scots pine to a slightly less than $10 \%$ for hornbeam and beech. From our limited sampling, the lowest concentrations of knot extractives were observed for hardwoods while the highest concentrations were observed for softwoods. Oak is inserted between two softwoods, and cherry knotwood concentration is very close to Douglas fir concentration. Hardwoods contained more hydrophilic and polar extractives as demonstrated by the large amounts of extractives obtained with the mixture toluene/ethanol or water, while softwoods contained higher amounts of extractives of lower polarity extracted with dichloromethane or acetone. Although knots of larch and Scots pine presented the highest extractive content, their composition varied significantly. Indeed, larch contained an important amount of aqueous extractives similar to hardwood species, while Scots pine knotwood extracts were mainly composed of lipophilic compounds. According to our results, knots of conifers were richer than those of hardwoods except in the case of oak which contained as much extracts as Norway spruce or silver fir knots. The contribution of each solvent in 
Fig. 1 Knotwood and heartwood extractive contents obtained by successive extractions with four solvents of increasing polarity $\square$ Dichloromethane $\square$ Acetone $\square$ Tol/Eth $\square$ Water

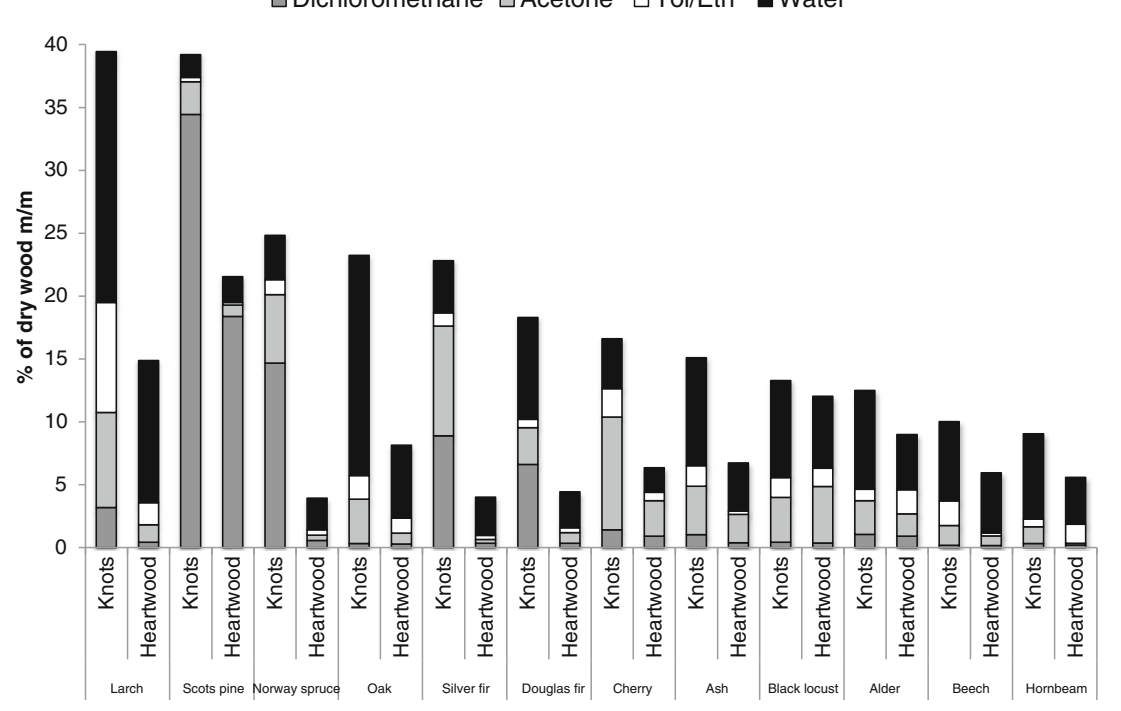

the total amount of extractives varied considerably according to the species.

\subsection{Identification of the extracted compounds}

GC-MS analyses were performed on knotwood and heartwood acetone extracts. Acetone was chosen as solvent because of its efficiency to extract lignans (Willför et al. 2003a, b). The main families of chemical identified in knots were terpenes, lignans, stilbens, flavonoids and sugar derivatives (Table 2).

Lignans were present mainly in conifer knots, Norway spruce and silver fir knots being the richest source of these compounds. Hydroxymatairesinol (HMR) was the most abundant lignan in Norway spruce knotwood, while secoisolariciresinol (SECO) was the dominant lignan in silver fir knotwood. SECO was also the most abundant lignan in the knotwood of Douglas fir and larch. Nortrachelogenin (NTG) was the main lignan in the knotwood of Scots pine, which is the only softwood species containing also stilbenes with pinosylvin and pinosylvin monomethyl ether as main components. Higher amounts of unknown compounds were present in Douglas fir knots compared to the other conifer knots. These compounds, not identified by GC-MS, are probably oligolignans as reported previously (Willför et al. 2003a, b, $2004 a, b, c)$. In the case of Norway spruce, $\alpha$-conidendrin was the only lignan detected in heartwood, while hydroxymatairesinol was the main lignan identified in knotwood. According to these results, knotwood of softwoods and to a lesser extent heartwood of some softwoods appear as an interesting source for the extraction of lignans as previously reported in the literature (Fig. 2).

Flavonoids like dihydrorobinetin, catechin and taxifolin were the main components identified in black locust, cherry and larch knotwood. Flavonoids were also reported in acacia knotwood (Pietarinen et al. 2005). Alder and Douglas fir also contained high amounts of flavonoids, with catechin and taxifolin being the dominant flavonoids. Our results are in accordance with former studies (Willför et al. 2003c; Lindberg et al. 2004; Pietarinen et al. 2006b). Beech knotwood contained small amounts of flavonoids consisting mainly of catechin. Flavonoid glycosides were not detected in the knotwood, although they were reported in the knotwood of poplar (Pietarinen et al. 2006a) and willow (Pohjamo et al. 2003). High quantities of carbohydrate derivatives, identified by GC-MS, could result from hydrolysis of the flavonoid glycosides or from the presence of sapwood in the knots sampled (Willför et al. 2005). Sugar derivatives are the main components identified in ash, beech and hornbeam knotwood. Sugar derivatives and gallic acid, probably resulting from hydrolysis of hydrolysable tannins, were the dominant compounds in oak knotwood. Abietic and dehydroabietic resin acids as well as palmitic, oleic and other fatty acids were detected in almost all the knotwoods. Small amounts of $\beta$ sitosterol were also detected in some knotwood.

Contrary to knotwood, lignans were practically absent from the heartwood of all studied softwoods except Norway spruce, which contains up to $13 \%$ of $\alpha$-conidendrin. Stilbenes, like pinosylvin and pinosylvin monomethyl ether, were detected as the main products contained in Scots pine heartwood. Flavonoids represent the most common family of extractives present in heartwood extracts: taxifolin, $36.4 \%$ in larch; dihydrochrysin and sakuranin, 29.0 and $24.3 \%$, respectively, in cherry and dihydrorobinetin, $63.8 \%$ in black locust.

\section{Discussion}

One of the first objectives of this study was to realize a first screening of the quantities of extractives present in knotwood 
Table 2 Percentage of the main identified products and main families of products detected in knotwood successive acetone extracts by GC-MS

\begin{tabular}{|c|c|c|c|c|c|}
\hline \multirow[t]{2}{*}{ Species } & \multicolumn{2}{|l|}{ Knotwood } & \multicolumn{2}{|l|}{ Heartwood } & \multirow[t]{2}{*}{ Family } \\
\hline & Compound, retention time (min) & $\begin{array}{l}\text { Relative } \\
\text { content }(\%)^{\mathrm{a}}\end{array}$ & $\begin{array}{l}\text { Compound, retention time } \\
\text { (min) }\end{array}$ & $\begin{array}{l}\text { Relative content } \\
(\%)^{\mathrm{a}}\end{array}$ & \\
\hline \multirow[t]{3}{*}{ Larch } & Taxifolin, 24.59 & 45.2 & \multirow[t]{3}{*}{ Taxifolin, 24.44} & \multirow[t]{3}{*}{36.4} & Flavonoid \\
\hline & Secoisolariciresinol, 24.77 & 22.4 & & & Lignan \\
\hline & Nortrachelogenin, 26.17 & 3.8 & & & Lignan \\
\hline \multirow[t]{3}{*}{ Scots pine } & Pinosylvin, 18.57 & 34.0 & Pinosylvin, 18.61 & 39.1 & Stilbene \\
\hline & Pinosylvin monomethyl ether, 18.81 & 42.0 & \multirow[t]{2}{*}{ Pinosylvin monomethyl ether, 18.83} & \multirow[t]{2}{*}{29.1} & Stilbene \\
\hline & Nortrachelogenin, 26.12 & 19.0 & & & Lignan \\
\hline \multirow[t]{3}{*}{ Norway spruce } & \multirow{3}{*}{$\begin{array}{l}\text { Hydroxymatairesinol and mixture of } \\
\text { diastereomers, } 26.33 \text { and } 26.45\end{array}$} & 64.3 & & & Lignan \\
\hline & & & $\alpha$-Conidendrin, 28.19 & 13.2 & Lignan \\
\hline & & & Fatty acids ${ }^{\mathrm{b}}$ & 12.3 & Fatty acid \\
\hline \multirow[t]{2}{*}{ Silver fir } & \multirow[t]{2}{*}{ Secoisolariciresinol, 24.07} & 26.6 & & & Lignin \\
\hline & & & \multirow[t]{3}{*}{ Fatty acids ${ }^{b}$} & \multirow[t]{3}{*}{22.5} & Fatty acid \\
\hline \multirow[t]{4}{*}{ Douglas fir } & Taxifolin, 24.51 & 5.8 & & & Flavonoid \\
\hline & Secoisolariciresinol, 24.73 & 9.0 & & & Lignan \\
\hline & \multirow[t]{2}{*}{ Phenylhexanoic acid, 13.43} & \multirow[t]{2}{*}{17.2} & Phenylhexanoic acid, 13.40 & 42.7 & \\
\hline & & & Juvabione, 16.48 & 20.9 & Terpenoid \\
\hline Oak & Gallic acid, 16.14 & 53.0 & Gallic acid, 16.14 & 17.6 & Phenol \\
\hline \multirow[t]{3}{*}{ Cherry } & \multirow[t]{3}{*}{ Catechin, 22.98} & \multirow[t]{3}{*}{47.5} & & & Flavonoid \\
\hline & & & Dihydrochrysin, 19.83 & 29.0 & Flavonoid \\
\hline & & & Sakuranin, 22.13 & 24.3 & Flavonoid \\
\hline \multirow[t]{5}{*}{ Ash } & Cinnamaldehyde, 15.40 & 2.7 & & & Phenyl propanoid \\
\hline & Fatty acids ${ }^{\mathrm{b}}$ & 5.6 & & & Fatty acid \\
\hline & \multirow[t]{3}{*}{$\beta$-Sitosterol, 29.03} & \multirow[t]{3}{*}{2.0} & & & Terpenoid \\
\hline & & & Fatty acids ${ }^{\mathrm{b}}$ & 20.9 & Fatty acid \\
\hline & & & Resin acids $^{\mathrm{c}}$ & 18.6 & Terpenoid \\
\hline Black locust & Dihydrorobinetin, 24.13 & 49.3 & Dihydrorobinetin, 24.16 & 63.8 & Flavonoid \\
\hline Alder & Catechin, 22.39 & 5.9 & Catechin, 22.93 & 3.0 & Flavonoid \\
\hline \multirow[t]{2}{*}{ Beech } & \multirow[t]{2}{*}{ Catechin, 22.95} & \multirow[t]{2}{*}{2.0} & & & Flavonoid \\
\hline & & & Palmitic acid, 16.84 & 6.3 & Fatty acid \\
\hline \multirow[t]{2}{*}{ Hornbeam } & $\beta$-Sitosterol, 28.92 & 4.1 & & & Terpenoid \\
\hline & Fatty acids ${ }^{\mathrm{b}}$ & 12.6 & Fatty acids ${ }^{\mathrm{b}}$ & 35.9 & Fatty acid \\
\hline
\end{tabular}

${ }^{a}$ Relative concentration (\%) were determined from the total ion chromatogram (TIC)

${ }^{\mathrm{b}}$ Fatty acids: palmitic acid, oleic acid, stearic acid, linoleic acid, etc.

${ }^{\mathrm{c}}$ Resin acids: abietic acid, dehydroabietic acid, pimaric acid, isopimaric acid, etc.

comparatively to those present in heartwood for different European softwood and hardwood species. For all studied species, knotwood contained higher amount of extractives than heartwood. The amount of extractives differed slightly from previous published data (Willför et al. 2003a, b, 2004a, b; Pietarinen et al. 2006b), likely because of the nature of the solvents used and the intra-specific variability. Nevertheless, the richness of the knotwood compared to the corresponding
Fig. 2 Structure of main lignans identified in knot and heartwood extractives<smiles>COc1cc(C[C@H]2C(=O)OC[C@@H]2[C@H](O)c2ccc(O)c(OC)c2)ccc1O</smiles> 
heartwood was confirmed. The fact that knotwood contains higher extractive amounts than heartwood suggests that knots are strategic points for the living tree. This finding supports the hypothesis that the junction between the trunk and branches are essential for a tree, ensuring sap flow between stem wood and leaves. These junctions also support important mechanical loads due to the weight of the branches and environmental factors like wind and precipitation which induce strong mechanical constraints. Changes in the fibre orientation surrounding knots as well as self-pruning of branches after their death could also be at the origin of entry for pathogens and oxygen which can damage living tissues of the stem. This is at least the case for beech wood red-heart phenomenon, which leads to a degradation of some chemical components (Bauch and Koch 2001). Therefore, knots must be both mechanically and decay resistant. Although large differences between species were found regarding the amounts and partition of the extractives between the different solvents used, knotwood extractive content is higher for all species studied (Fig. 1). Amount of extractives solubilized in the different solvents indicated an important heterogeneity between species of the extractives present in knots. Indeed, while dichloromethane is able to solubilize most of the extractives present in Scots pine and spruce, acetone dissolved the highest fraction of extractives in the case of fir or cherry and water in the case of other wood species like oak, black locust or larch...

Knotwood of softwoods contains mainly lignans, whereas knotwood of hardwoods contains mainly flavonoids, tannins and/or sugars. Surprisingly, lignans were not detected in hardwood knots sampled in our study. On the basis of implication of coniferylic alcohol in the biosynthesis of both lignans and lignins (Suzuki and Umezawa 2007), high lignan contents in coniferous knots suggest that lignans may play a specific role in the formation of compression wood developed in softwoods, which is highly lignified (Timell 1982). Interestingly, Willför et al. (2003a) reported that compression wood in Norway spruce knots contained less lignans than the opposite wood in the same knot, suggesting the potential implications in the lignification process to reinforce knot tissues involved in branches support. On the other hand, tension wood developed in hardwood species is reported to contain higher polysaccharide contents, which could be in agreement with the higher sugar derivative contents detected in hardwood extracts. However, these hypotheses according to which softwood species mobilize lignans to reinforce compression wood, while hardwood species mobilize sugars to reinforce tension wood are speculative and need further investigation. Another explanation of the higher amounts of extractives in knotwood may be connected to their role in wood durability and protection against biotic and abiotic agents. Lignans are abundant in softwoods and are known to be good antioxidants and radical scavengers (Willför et al. 2003c; Pietarinen et al. 2006b). Extractives may protect heartwood using at least three different mechanisms: fungicidal activity, free radical scavenging/antioxidation and metal chelation (Schultz and Nicholas 2000, 2002). Moreover, either natural or synthetic antioxidants have been reported to present synergistic effects with antifungal agents (Yen and Chang 2008; Mabicka et al. 2005). Presence of lignans may therefore be essential to protect the wood surrounding the knot against pathogens and oxidative injuries. Similarly, flavonoids are known to possess fungicidal properties (Neascu et al. 2007), meaning that these compounds present in the knots of cherry, alder and black locust may retard the progression of wood decay fungi. A similar effect may be involved in the case of oak knots, which contained important amounts of hydrolysable tannins, reported to be involved in oak wood durability (Aloui et al. 2004). Besides the differences concerning the amounts of extractives observed between knotwood and heartwood, the chemical composition of extractives differs more or less between these two types of wood. We observed that some compounds found in knotwood are also present in heartwood, like taxifolin in larch, stilbenes in Scots pine, dihydrorobinetin in black locust or gallic acid in oak. We observed also that chemical composition of knotwood and heartwood may also differ considerably. Indeed, the repartitioning of the main families of products detected in knotwood and heartwood successive acetone extracts by GC-MS presented important differences for several species (Fig. 3).

Overall chemical composition may also vary considerably as for Norway spruce and silver fir for which knotwood extracts contained mainly lignans, which are only present in small quantity or totally absent from heartwood (Fig. 3). This is not the case for Scots pine, for which knotwood and heartwood extractives are mainly constituted of stilbenes and for cherry and black locust for which both type of wood contains mainly flavonoids. It turns out that lignans appear to be specific extractives of softwood knots. On the other hand, as previously indicated, knotwood of hardwood contains an important amount of saccharides which may also be present in hardwoods like alder. These differences of chemical composition of knots of softwood containing mainly lignans and knots of hardwood containing mainly saccharides suggest a possible implication of these extractives in compression and tension wood formation, while phenolic compounds like lignans, flavonoids, stilbenes or tannins are likely involved in defence strategies. 
Fig. 3 Repartition of the main families of products detected in knotwood and heartwood successive acetone extracts by GC-MS (relative concentration were determined from the TIC) घignans $\square$ Flavonoids $\approx$ Stilbenes $\square$ Saccharides $\square$ Others $\square$ Unidentified

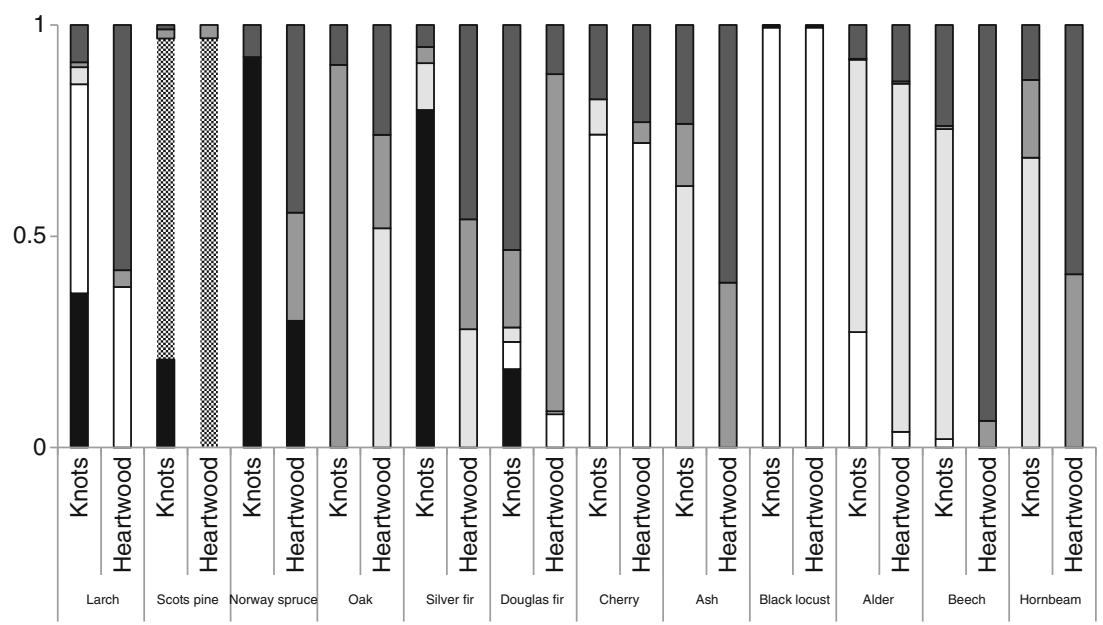

Considering the fact that alder, cherry and black locust are commonly considered as rather bad pruning species, it is interesting to mention that the knots of those trees contained higher quantities of flavonoids compared to the knots of the other hardwoods $C$. betulus, F. sylvatica, F. excelsior and $Q$. petraea. These flavonoids may slow down the dynamics of biotic and abiotic agents involved in the degradation of dead branches during natural pruning. The other hardwoods that self-prune easily (Schütz 1990) were found to contain no or small traces of flavonoids. Good pruning of oak branches, for which knots contain mainly hydrolysable tannins, may be due to the poor resistance of these compounds to leaching. Similar arguments may explain the lack of natural pruning ability in Norway spruce, silver fir and Douglas fir based on the high quantities of lignans contained in these species. These observations are in agreement with the observation that the knots of $A$. angustifolia, which remained intact in forest for several years, were found to contain $90 \%$ of lignans among their overall extracts (Anderegg and Rowe 1974). However, the presence of lignans in larch and Scots pine, which are considered as having a good pruning ability, make this interpretation likely dependent on the species. This suggests that lignans may perform other functions in the wood and that degradation of the outside branches and extractive content of the internal knot may be not systematically related for all species.

\section{Conclusion}

This study confirms that independently of the nature of the species studied, knots contain always higher extractive content than corresponding heartwood. The composition and the amount of knotwood extractives were found to vary considerably between the 12 trees species investigated in this study. Lignans were confirmed to be present in all the softwoods studied, while they were totally lacking in hardwoods which were shown to contain flavonoids and saccharides. Even if the role of lignans in lignin formation is still under discussion, an explanation of the presence of lignans in softwoods may be their involvement in lignification of compression wood. Compression wood is reported to contain higher amounts of lignin than "normal" wood. The fact that tension wood is reported to contain higher amounts of polysaccharides could be in accordance with the high amount of saccharides detected in hardwood knots. However, these hypotheses are purely speculative and further studies are necessary to obtain deeper insight on the role of these extractives. High extractive content and nature of these extractives may also be involved in defence strategy and branch departure constituting potential weakness subjected to biotic and abiotic injuries. Extractives may also be involved in the natural ability of trees to self-prune. Wood species with high flavonoid content were generally bad pruning species. Although a lot of work to understand the exact role of extractives present in the knots and their specificity according to wood species remain, these results clearly demonstrate that knots are a valuable source of biomolecules like lignans or flavonoids susceptible to further industrial processing. However, a deeper assessment of the forest resource in knotwood extractives is needed for the most promising wood species to evaluate the effect of the within-tree and intraspecific variability before industrial development.

Acknowledgments Authors thank warmly Bruno Garnier, Loïc Dailly, Alain Mercanti and Nicolas Houssement for their technical support. The authors gratefully acknowledge the Institut National de la Recherche Agronomique (INRA) for the doctoral fellowship granted to the first author (CJS no. 12-00006889). The UMR 1092 LERFoB and EA 4370 LERMAB are supported by a grant overseen by the French National Research Agency (ANR) as part of the "Investissements d'Avenir" programme (ANR-11-LABX-0002-01, Lab of Excellence ARBRE). Thanks at last to the forest managers D. Collinet and Y. Ehrhardt, respectively, from the National Forest Service ONF and AgroParisTech who provided the material from the Champenoux and Amance forests. 


\section{References}

Aloui F, Ayadi N, Charrier F, Charrier B (2004) Durability of European oak (Quercus petraea and Quercus robur) against white rot fungi (Coriolus versicolor): relations with phenol extractives. Holz als Roh- und Werkstoff 62:286-290. doi:10.1007/s00107-004-0489-7

Anderegg RJ, Rowe JW (1974) Lignans, the major component of resin from Araucaria angustifolia knots. Holzforschung 28:171-175. doi: 10.1515/hfsg. 1974.28.5.171

Bauch J, Koch G (2001) Biological and chemical analyses about wood discolourations of common beech (Fagus sylvatica [L.]) and possibilities of preventing measures]. Final Report, Bundesforschungsanstalt für Forstund Holzwirtschaft, Universität Hamburg, 66 pp

Eklund P, Langvik O, Warna J, Salmi T, Willfor S, Sjoholm R (2005) Chemical studies on antioxidant mechanisms and free radical scavenging properties of lignans. Organic and Biomolar Chem 3:33363347. doi:10.1039/B506739A

Ekman R (1976) Analysis of lignans in Norway spruce by combined gas chromatography-mass spectrometry. Holzforschung 30:79-85. doi: 10.1515/hfsg.1976.30.3.79

Ekman R, Willför S, Sjöholm R, Reunanen M, Mäki J, Lehtilä R, Eckerman C (2002) Identification of the lignan nortrachelogenin in knot and branch heartwood of Scots pine (pinus sylvestris L.). Holzforschung 56:253-256. doi:10.1515/HF.2002.041

Holmbom B, Eckerman C, Eklund P, Hemming J, Nisula L, Reunanen M, Sjöholm R, Sundberg A, Sundberg K, Willför S (2003) Knots in trees - a new rich source of lignans. Phytochem Rev 2:331-340. doi:10.1023/B:PHYT.0000045493.95074.a8

Kirker GT, Blodgett AB, Arango RA, Lebow PK, Clausen CA (2013) The role of extractives in naturally durable wood species. Int Biodeterior Biodegrad 82:53-58. doi:10.1016/j.ibiod.2013.03.007

Lindberg LE, Willför SM, Holmbom BR (2004) Antibacterial effects of knotwood extractives on paper mill bacteria. J Ind Microbiol Biotechnol 31:137-147. doi:10.1007/s10295-004-0132-y

Lundquist K, Langer V, Li S, Stomberg R (2003) Lignin stereochemistry and its biosynthetic implications. $12^{\text {th }}$ international synmposium on wood and pulping chemistry, USA 239-244

Mabicka A, Dumarçay S, Rouhier N, Linder M, Jacquot JP, Gérardin P, Gelhaye E (2005) Synergistic wood preservatives involving EDTA, Irganox 1076 and 2-hydroxypyridine- $N$-oxide. Int Biodeterior Biodegrad 55:203-211. doi:10.1016/j.ibiod.2005.01.002

Neacsu M, Eklund PC, Sjöholm RE, Pietarinen SP, Ahotupa MO, Holmbom BR, Willför SM (2007) Antioxidant flavonoids from knotwood of Jack pine and European aspen. Holz Roh Werkst 65: 1-6. doi:10.1007/s00107-006-0121-0

Pietarinen P, Willför SM, Sjöholm RE, Holmbom BR (2005) Bioactive phenolic substances in industrially important tree species. Part 3 : Knots and heartwood of Acacia crassicarpa and A. mangium. Holzforschung 59:94-101. doi:10.1515/HF.2005.015

Pietarinen SP, Suivi P, Willför SM, Vikström FA, Holmbom BR (2006a) Aspen knots, a rich source of flavonoids. J Wood Chem Technol 26: 245-258. doi:10.1080/02773810601023487

Pietarinen SP, Willför SM, Ahotupa MO, Hemming JE, Holmbom BR (2006b) Knotwood and bark extracts: strong antioxidants from waste materials. J Wood Sci 52:436-444. doi:10.1007/s10086005-0780-1

Piispanen R, Willför S, Saranpää P, Holmbom B (2008) Variation of lignans in Norway spruce (Picea abies [L.] Karst.) knotwood: within-stem variation and the effect of fertilisation at two experimental sites in Finland. Trees-Struct Funct 22:317-328. doi:10. 1007/s00468-007-0186-3
Pohjamo SP, Hemming JE, Willför SM, Reunanen MHT, Holmbom BR (2003) Phenolic extractives in salix caprea wood and knots. Phytochem 63:165-169. doi:10.1016/S0031-9422(03)00050-5

Rameau JC, Mansion D, Dumé G, Timbal J, Lecointe A, Dupont P, Keller R (1989) Flore forestière Française, guide écologique illustré. 1. Plaines et collines. Institut pour le développement forestier. Ministère de l'agriculture et de la forêt. Ecole nationale du génie rural des eaux et des forêts.

Schultz TP, Nicholas DD (2000) Naturally durable heartwood: evidence for a proposed dual defensive function of the extractives. Phytochem 54:47-52. doi:10.1016/S0031-9422(99)00622-6

Schultz TP, Nicholas DD (2002) Development of environmentallybenign wood preservatives based on the combination of organic biocides with antioxidants and metal chelators. Phytochem 61: $555-560$

Schütz (1990) Sylviculture 1. Principes d'education des forets. Presses Polytechniques et Universitaires Romandes, Lausanne; Switzerland 243p pp

Sekine N, Shibutani S, Yatagai M (2013) Chemical composition of the terpenoids in wood and knots of Abies species. Eur J Wood Wood Prod 71:679-682. doi:10.1007/s00107-013-0715-2

Smeds AI, Ceskova I, Eklund PC, Willför SM (2012) Identification of new lignans in Norway spruce knotwood extracts. Holzforschung 66:553-567. doi:10.1515/hf-2011-0218

Suzuki S, Umezawa T (2007) Biosynthesis of lignans and norlignans. J Wood Sci 53:273-284. doi:10.1007/s10086-007-0892-x

Timell TE (1982) Recent progress in the chemistry and topochemistry of compression wood. Wood Sci Technol 16:83-122. doi:10.1007/ BF00351097

Willför SM, Hemming J, Reunanen M, Eckerman C, Holmbom BR (2003a) Lignans and lipophilic extractives in Norway spruce knots and heartwood. Holzforschung 57:27-36. doi:10.1515/HF.2003. 005

Willför SM, Hemming J, Reunanen M, Holmbom B (2003b) Phenolic and lipophilic extractives in Scots pine knots and heartwood. Holzforschung 57:359-372. doi:10.1515/HF.2003.054

Willför SM, Ahotupa MO, Hemming JE, Reunanen MHT, Eklund PC, Sjöholm RE, Eckerman CSE, Pohjamo SP, Holmbom BR (2003c) Antioxidant activity of knotwood extractives and phenolic compounds of selected tree species. J Agric Food Chem 51:76007606. doi:10.1021/jf030445h

Willför SM, Nisula L, Hemming J, Reunanen M, Holmbom BR (2004a) Bioactive phenolic substances in industrially important tree species. Part 1: Knots and heartwood of different spruce species. Holzforschung 58:335-344. doi:10.1515/HF.2004.052

Willför SM, Nisula L, Hemming J, Reunanen M, Holmbom BR (2004b) Bioactive phenolic substances in industrially important tree species. Part 2 : Knots and heartwood of fir species. Holzforschung 58:650 659. doi:10.1515/HF.2004.119

Willför SM, Reunanen M, Eklund P, Sjöholm R, Kronberg L, Fardim P, Pietarinen S, Holmbom B (2004c) Oligolignans in Norway spruce and Scots pine knots and Norway spruce heartwood. Holzforschung 58:345-354. doi:10.1515/HF.2004.053

Willför SM, Eklund P, Sjöholm R, Reunanen M, Sillanpää R, Von Schoultz S, Hemming J, Nisula L, Holmbom BR (2005) Bioactive phenolic substances in industrially important tree species. Part 4 : Identification of two new 7-hydroxy divanillyl butyrolactol lignans in some spruce, fir, and pine species. Holzforschung 59:413-417. doi:10.1515/HF.2005.067

Yen TB, Chang ST (2008) Synergistic effects of cinnamaldehyde in combination with eugenol against wood decay fungi. Bioresour Technol 99:232-236. doi:10.1016/j.biortech.2006.11.022 